\title{
Knowledge, Attitude and Intention to Future Practice of Female Genital Mutilation among Medical Students, Egypt
}

\author{
Alshaimaa M. Abdelmoaty ${ }^{1 *}$, Hend A. Sabry ${ }^{1}$, Reham Y. Elamir ${ }^{1}$ \\ ${ }^{1}$ Public Health and Community Medicine Department, Faculty of Medicine, Cairo University
}

\begin{abstract}
:
Background: There is no medical indication for Female Genital Mutilation/Cutting (FGM/C) a procedure with wide range of complications. In Egypt, around 50\% of the population supports the practice; moreover, health care providers contrary to their original role in eliminating such harmful practice perform about $80 \%$ of the FGM. In Egypt, the knowledge and attitudes of medical students about FGM are questionable. Objectives: To explore the level of knowledge and attitudes towards FGM/C and identifying the possible predictors favouring its practice among medical students.

Methods: A cross-sectional study, 630 medical students were included. Self-administered anonymous data collection form was used. Results: Females demonstrated significant higher knowledge score 4.5 (3.5-5.5) with more negative attitude towards FGM/C. Males with low knowledge score 5 (4.0-6.0) were the significant predictors for future FGM/C practice among the included sample.Conclusions: Medical students especially males are not sufficiently knowledgeable about FGM/C; some of them would perform $\mathrm{FGM} / \mathrm{C}$ in their future practice.
\end{abstract}

Key words: Egypt, Female Genital Mutilation, Female Genital Cutting, Kasr Al Ainy, Cairo University, Medical students

\section{Introduction:}

Female genital mutilation (FGM/C) is an important global issue of interest attracting policy-makers' attention attributed to its direct effect on women's health and representing an explicit of gender-based violence. ${ }^{(1)}$ Globally, it is estimated that 100-140 million girls and women have undergone FGM/C. ${ }^{(2)}$ Different types of FGM/C procedures are identified including complete removal of clitoris. ${ }^{(3)}$

In many developing countries, the practice may involve females before marriage or even with the birth of their first child. ${ }^{(4)}$ In Egypt 50\% of the girls had undergone FGM/C between 5 and 10 years of age and more than $80 \%$ of them were performed by health care providers. Moreover, about $50 \%$ of the population supports the practice believing it is a religious required ritual. ${ }^{(5)}$ FGM/C may appear as a surgical procedure that lay people with no training in surgery or hygienic practice often done $\mathrm{it}^{(6)}$, especially among poor families; it could be resorted to a senior female in the family or the neighbourhood, or by traditional practitioners, midwives or barbers, ${ }^{(4)}$ using any sharp unsterilized objects including scissors, and razor blades or even broken glass. ${ }^{(7)}$

The FGM/C is an ancient cultural practice, predating the Bible and the Koran and has no basis in any religion ${ }^{(8)}$. FGM/C is currently practiced in over 26 countries in Africa, Middle East and some countries in Asia, with a prevalence of $70 \%$ or more reported in eleven African countries including Egypt. ${ }^{(9)}$ Regardless the social class, educational background or religious affiliation $\mathrm{FGM} / \mathrm{C}$ is practiced at all segments of Egyptian society and there is support from some women towards its continuation despite the absence of medical or health indications. ${ }^{(10)}$

The immediate and long-term consequences of FGM/C are well known, 
ranging from severe pain and urinary incontinence, difficulties in menstruation to excessive haemorrhage and scarring. Serious infections may lead to septicemia and may cause death. Potential of benign tumours and clitoral cysts, painful coital penetration, psychological problems as anxiety and/or depression. ${ }^{(6)}$ Previously, some providers advocated the option of carrying FGM/C in medical facilities under hygienic conditions known as "the medicalization of FGM/C" by skilled providers so that it becomes less risky ${ }^{(6)}$, this was seen as a window for FGM/C supporters to continue the practice. $^{(11)}$

However, this step shifted the attention away from considering the act as a human rights violation issues to mere guarding against its harmful health consequences. ${ }^{(4)}$

Performing the FGM/C by health-care professionals represents a break in medical professionalism, ethical responsibility, and violation of law. World Health Organization "strongly condemns the medicalization of FGM/C-in any setting, including hospitals or other health establishments."(3) The FGM/C has been practiced in Egypt since antiquity and hence it is deeply rooted culturally ${ }^{(12)}$. For more than six decades, many health organizations prioritized to raise the world's awareness about FGM/C practice and looked for ways to decrease its incidence ${ }^{(13)}$. In 2007, the Egyptian parliament had criminalized the practice in response to the tragic death of an adolescent girl in Upper Egypt who underwent FGM/C resulted in haemorrhage. ${ }^{(14)}$ Despite being criminalized, the prevalence of FGM has been reported as 97\% in Upper Egypt and 61\% in Lower Egypt and still widely practiced covertly. ${ }^{(15)}$

Gynecologists and perhaps nurses are no longer welling to perform FGM/C after criminalization, Families too being more aware about the possible complications yet demanding FGM/C practice found a way to seek it from general practitioners who filled the gap clearly with less fees compared to gynaecologists and can deal in a more professional way with the complications than nurses. Combating FGM practice necessitates efforts to change the mindsets of health professionals. ${ }^{(16)}$ Improving the general practitioner's education about reproductive health increase the chances of success to eliminate FGM practice. ${ }^{(17)}$

In order to solicit the active involvement of health providers as advocates against FGM/C, they should be equipped with appropriate knowledge and skills enabling them to work for its prevention and elimination. They also should provide sound clinical and psychological care and support for girls and women who have undergone the procedure, taking into consideration the sociocultural and personal sensitivities. ${ }^{(5)}$ Neither FGM/C as a practice nor how to manage its complications is included in pre- or post-graduate curricula of nurses, midwives and physicians at any university in Egypt. Interventions that could improve 
healthcare of women with FGM/C and the prevention of the practice have been rarely investigate. ${ }^{(18)}$

Circumcised women have specific health care needs and knowledgeable health care providers are essential in ensuring proper screening, diagnosis, care, counseling and prevention. ${ }^{(19)}$ Since the overall prevalence of FGM/C in Egypt is still high and eradication of such harmful ritual is a serious challenge augmented by the lack of knowledge among health care providers including medical students have a great impact on the continuity of performing FGM/C.

This study was conducted to assess the knowledge and attitude of medical students at Cairo University who are going to be the future physicians towards FGM/C.

\section{Methods:}

Setting and Design: This cross-sectional study was conducted in Kasr Al Ainy Medical School, Cairo University.

Sampling: The study targeted Egyptian Medical students at Kasr Al Ainy Medical School during the period from September $15^{\text {th }}$ 2016-May $31^{\text {st }}$ 2017. The sample size was calculated using open-epi online calculator (http://www.openepi.com/SampleSize/SSPropo r.htm). In response to the scarcity of previous studies regarding the topic in Egypt, the proportion of students with knowledge about FGM/C is taken as $50 \%$; the required sample size was 537 students. Adding a $20 \%$ for the possible non-response, the final sample size would include 645 students.

Multistage sampling was used for the recruitment of participants, in the first stage, stratified random sampling method was used at each year in the college ( $2^{\text {nd }}$ to $6^{\text {th }}$ year), to guarantee representation of the both genders. In the second stage, a systematic random sampling was applied to select students in each stratum using statistical software (SPSS 21.0, Statistical package for Social Science) through employing of the students' academic number.

Those selected were personally invited to participate into the study following appropriate orientation about the objectives and the possible impact, emphasizing on their right not to participate.

Data Collection: Participants were invited to fill out a self-administered anonymous questionnaire form (in English, as it is the formal educational language used at the site of the study) to gather information on the following sections:

a- Socio demographics: age in years, gender, academic year, religion, marital status and whether circumcised or not (for females only).

b- Knowledge and attitude about FGM/C: Several items were adopted from the available literature, ${ }^{(5,20)}$ the primary form contained 19 items: 13 for the knowledge section and 6 items pertained 
to the attitudes towards FGM/C to collect information about:

- FGM/C Knowledge: its types, complications, effect on reproductive health, legality and if it increases the chance of marriage for females. All items were close-ended with multiple options format.

- Attitude towards FGM/C: encouraging, criminalization, continuation of the practice, reasons favoring their willingness to have their future daughters circumcised and one special question about the preference of males to marry a circumcised female. All items were provided with multiple options (agree, disagree, not decided/yes, no and do not know).

- One last question was designed to assess their future willingness to practice FGM/C in the future.

The tool was pilot tested on a non-probability convenience sample of 50 students in the $4^{\text {th }}$ year (beyond the sample size and they were excluded from the sampling frame) to clarify terms and assess any potential difficulty in questionnaire administration.

During the pilot phase the provisional data collection tool showed an internal reliability coefficient (Cronbach' alpha) of .643 (13 items) increased to .741 after removal of 3 items (namely assessing their knowledge towards the effect of FGM/ C on sexuality). For the attitude component, the construct (6 items) yielded an internal consistency reliability coefficient (Cronbach' alpha) of .783.

Statistical Analysis: Data entry and analysis were carried out using SPSS 21.0 (SPSS Inc. IBM, USA). The total eligible questionnaires for final analysis were 630 (response rate of 97.6\%). For the knowledge section correct response for item received one point, while incorrect and do not know response received nil. Total knowledge score was expressed using mean, median and interquartile range (IQR). Nonparametric tests of significance namely Mann Whitney were used for comparison of continuous variables. Categorical variables were reported as proportions with $95 \%$ confidence intervals (CI); Chi-square test for independence for was used for comparison when appropriate. $\mathrm{P}$ value of $<0.05$ was considered significant.

Ethical Considerations: Faculty of medicine Cairo university ethical committee approved the study. Participants were provided with full explanation of the study with the emphasis on the right of not to participate.

\section{Results:}

Of the total 630 students participated, 370 $(58.3 \%)$ were females and $260(41.3 \%)$ were males with a mean age $21 \pm 1.5$ years of for the whole sample, $86 \%$ and $88.3 \%$ of males and females respectively were Muslims, while $14 \%$ and $11.7 \%$ of males and females respectively were Christians. Apart from $0.8 \%$ of them are 
married, all of them were singles. Of the included female students 45 (12.6\%) were circumcised and $14(3.7 \%)$ refused to mention their status.

Out of the included medical students, $36.5 \%$ could not mention any known type of FGM/C; this was slightly more among males while only $3.8 \%$ correctly mentioned the four types of FGM/C. All forms of FGM/C are harmful as responded by $58.7 \%$ of the total sample, significantly among females compared males (61.9\% compared to $54.2 \%$ among males). More than $80 \%$ of the included students' stated correctly three to four possible reproductive complications of FGM/C with no significant difference in relation to gender of students. FGM/C is not based on evidence correctly answered by $82.1 \%$ of the respondents. More than $60 \%$ of the sample stated that FGM/C decreases sexual promiscuity in females, this was significantly higher among male students ( $75 \%$ vs. $56.9 \%$ among females).Nine out of ten and 6 for every ten students mentioned that FGM/C decreases sexual pleasure and causes sexual dysfunction in females. FGM/C makes the female genitalia more attractive as stated by $39.4 \%$ of the included students, with more in favour of this answer among male respondents (Table 1).

More than $50 \%$ and $32 \%$ of the included males and female students respectively believed that FGM/C increases the chance of marriage in circumcised females $(\mathrm{P}=0.020)$. Contrary to the expected, $26.8 \%$ of the participants expressed that $\mathrm{FGM} / \mathrm{C}$ practice is not against the law (significantly more among male students) while overall more than $73 \%$ of the included students mentioned that $\mathrm{FGM} / \mathrm{C}$ is unlawful practice. The total knowledge score was significantly higher among females compared to males where out of the ten points included, females were more knowledgeable than males, Females had median knowledge score: (median 5, and interquartile range (IQR) of 4-6 compared to males with a median of 4.5 and IQR of 3.5-5.5 points (Table 1). Also, students at the clinical years $\left(4^{\text {th }}, 5^{\text {th }}\right.$ and $6^{\text {th }}$ years $)$ scored significant higher (median 5 and interquartile range (IQR) of 4-6 points compared to those in than students in $2^{\text {nd }}$ and $3^{\text {rd }}$ years (academic education) with a median of 4.5, and IQR of 3.5-5.5 points (Figure $1)$.

For the attitude items, females appeared to be against the FGM/C practice compared to the included males (Table 2). Nine out of ten females compared to 8 out of ten males disagree to encourage the practice, $77.4 \%$ of the females compared to $63 \%$ of males believed that FGM/C should be legalized against and $67.6 \%$ of the participants decline the males preference to marry circumcised female $(70.2 \%$ among males compared to $41.7 \%$ among females, $\mathrm{P}=0.001$ ). Of the included students ( $\mathrm{n}=630), 502(83.3 \%)$ disagreed for the continuation of the FGM/C practice. For the future intentions to circumcised their daughters, $4.1 \%$ stated that they will and 
9.9\% were not yet decided (significantly more among males compared to females, $\mathrm{P}=0.001$ ).

Out the total participants, $28.1 \%$ were in favour of FGM/C significantly more in males $(33.1 \%$ vs. 24.6 in females), religious and socio-cultural reasons were mentioned by more than $65 \%$ and $74 \%$ in both males and females respectively. Students who are not in favour of FGM/C demonstrated significantly higher median knowledge score (5 points with IQR 4-6 compared to those who are in favour of FGM (median of 3.5, IQR 2.5-5.0. (Figure 2)

The possible predictors for future practicing of FGM among the surveyed medical students as revealed from bivariate analysis showed that males rather than female (Odds ratio (OR) of 1.5 with $95 \%$ confidence intervals $(\mathrm{CI})=1.04-$ 2.57) was the sole positive predictor while being more knowledgeable (score of $\geq 6$ points) appeared to negatively influence the future practice of FGM/C among the surveyed medical students $\quad(\mathrm{OR}=5.09, \quad \mathrm{CI}=2.51-10.3) . \quad$ Age, religion and the type of medical education (academic vs. clinical) were not significantly affecting the future intension to practice FGM/C (Table 3).

\section{Discussion:}

This study revealed inadequacy of medical students' knowledge, the total knowledge score was significantly higher among females compared to males coupled with favouring attitude towards FGM/C among males compared to females who appeared to be against the FGM/C practice.

Furthermore, the included female students demonstrated higher level of knowledge than males being FGM/C is a harmful practice and against the law, while males responded that FGM reduces promiscuity and increases the chance of the female to get married.

The discrepancy in the level of knowledge between both sexes sharing the same educational program reflects the weak impact of the educational content to be able to correct the effect of the prevailing deeply rooted culture towards FGM/C. Similar results were reported in a similar study was conducted among medical students in Alexandria University-Egypt where the investigators found that the basic knowledge about FGM practice was unsatisfactory and only $21.5 \%$ of the students cited the medical curricula as the source of their knowledge. ${ }^{(5)}$

These results highlight the insufficiencies in the underground medical curricula regarding FGM/C and consequently the expected knowledge of the future general practitioners knowledge regarding this harmful practice. Studies conducted in more developed countries are scarce though in a trial to compare our results we surprisingly found that three quarters of health care professionals in United Kingdom were aware about the FGM/C types and complications ${ }^{(21)}$ compared to $40 \%$ as reported by ${ }^{(22)}$ in the same region few years earlier. ${ }^{(21)}$ 
Out of the included female medical students in this study, $12.6 \%$ were circumcised and $3.7 \%$ refused to mention their status; less than what was reported by Herieka and Dhar, $2003^{(20)}$ in their reported results of medical students in Khartoum University in Sudan (56.8\%). The above-mentioned prevalence of FGM/C among our sample reported may not reflect the true prevalence of $\mathrm{FGM} / \mathrm{C}$ in the Egyptian community as the socioeconomic, educational and cultural status affect the risk of exposure to the practice ${ }^{(23)}$ where higher educational level of the family is associated with lower exposure to $\mathrm{FGM} / \mathrm{C}$.

Over all, the surveyed sample expressed a negative attitude towards FGM/C, refusing this practice to continue, females appeared to be more against the practice than males. Similar findings were reported among Suez Canal University's medical students where $61 \%$ of medical students expressed their intentions not perform the practice in their future practice and $52 \%$ mentioned they would fight this practice within their families. ${ }^{(24)}$

Moustafa et al in their study reported that 50 $\%$ of the surveyed medical students at Alexandria University, were against this practice both males and females were similar with no significant differences and mentioned they could contribute in stopping this practice in their future career and the other 50\% supported FGM/C practice and $31.9 \%$ expressed their intension to subject their Future daughters to circumcision ${ }^{(5)}$. Different findings were reported from the surveyed general practitioners and nurses in Upper Egypt where $88.2 \%$ of the nurses and $34.3 \%$ of the young physicians' attitudes were in favor of $\mathrm{FGM} / \mathrm{C}$ practice being a tradition that cannot be stopped, $97.4 \%$ of them defended that $\mathrm{FGM} / \mathrm{C}$ is prescribed by religion and $47.9 \%$ would subject their daughters to FGM/C in the future. ${ }^{(17)}$

In Egypt, despite the criminalization law, the attitudes of some health care providers against FGM/C is still unsatisfactory, may be marketing for the law is still deficient and needs to be enforced. In this study $77.4 \%$ of females and $67.6 \%$ males of medical students, mentioned FGM/C should be legislated and criminalized by law. It is evident that; half of the surveyed students thought that criminalization of FGM/C could prevent the future practice as a first step, $49 \%$ expressed their fear if health care professionals refuse to perform FGM may lead to shifting to the traditional circumcision being a final resort of the families opening the door to painful and unhygienic practices with more complications. ${ }^{(5)}$

Relph et al, $2013^{(21)}$, found that $10 \%$ of the included participants were in favour of FGM/C medicalization and they believed that the practice could be safer with fewer complications.

In this study, $67.6 \%$ of the surveyed students declined the male preference to marry a circumcised female and that misconception that 
FGM/C increases the chance of the females to get married. This is not consistent with the findings reported by Herieka and Dhar, $2003^{(20)}$ where $74.8 \%$ of the included males would prefer to marry a non-circumcised female and $91.7 \%$ of the females responded they don't believe that circumcision increase their chance to get married, this discrepancy can be explained on the ground of socio-cultural differences between developed and developing countries including Egypt.

In this study, the possible predictors for future practicing of FGM among the surveyed medical students showed being less knowledgeable male practitioner appeared to influence the future practice of FGM/C. While student's age, religion and the type of medical education were not affecting the future intention of FGM/C practice among medical students. This emphasizes the importance of raising the awareness of medical students especially males. ${ }^{(5,17)}$ The available literature showed that knowledgeable University students refuses the practice to continue and the effect is exponential if females are included, a key element towards eradicating this practice that violates the human rights. ${ }^{(20)}$

Study limitations: The study was limited to Faculty of Medicine Cairo University students and its results cannot be extrapolated to all Egyptian Medical schools or universities. FGM/C topic in the Egyptian community has a peculiar sensitivity regardless the socio- economic and strata and educational status, and this was obviously noticed during the data collection phase in the form of refusal to participate, refusal to sign a written consent and missing responses to some items.

Nevertheless, the current study provided data suggesting interventional strategies toward eliminating of FGM/C at the level of undergraduate medical students. The adverse effects of FGM/C on the reproductive health must be early introduced and emphasized in medical curricula. Sufficient knowledge and training about the possible hazards, complications and management of FGM/C being a prevalent practice in the Egyptian community and to prepare them to make the required changes in their community.

Conclusion: Medical students at Kasr Al Ainy school of Medicine, Cairo University demonstrated insufficiently knowledge about FGM/C. A sizable portion of male students would perform FGM/C in their future practice. Revising the current curricula emphasizing the complications and criminalization of the practice is of great necessity to help accelerate the elimination of such harmful practice.

Acknowledgment: To all the study participants who participated in this work.

Fund: The research was conducted with no fund.

Conflict of Interest: There is no conflict of interest as well.

\section{References:}


1. Onuh SO, Igberase GO, Umeora JO, et al. Female genital mutilation: Knowledge, attitude and practice among nurses. J Natl Med Assoc.2006: 98:409-14.

2. WHO. Eliminating female genital mutilation: the imperative 2008. Available from:http://whqlibdoc.who.int/publications/ 2008/9789241596442_eng.pdf.Accessed on January 2018.

3. WHO. Global Strategy to stop health-care providers from performing female genital mutilation UNAIDS, UNDP, UNFPA, UNICEF, UNHCR, UNIFEM, WHO, FIGO, ICN, IOM, WCPT, WMA, MWIA. WHO/RHR/10.9.2018.

Available from:http://www.who.int/reproductivehealt h/publications/fgm/rhr_10_9/en/ (Accessed January2018).

4. UNICEF. Female Genital Mutilation/Cutting: A $\quad$ Statistical Exploration 2005.

ISBN-13:978-92-806-3941-4;ISBN-10:92806-3941-2

5. Mostafa SR, El Zeiny NA, Tayel SES,et al. What do medical students in Alexandria know about female? La Revue de Santé de la Méditerranée orientale.2006; Vol. 12 (Supplement No 2).

6. Sundby J. Female genital mutilation. Lancet. 2003;362 Suppl: s26-7.

7. Dalal K, Lawoko S, Jansson B. Women's attitudes towards discontinuation of female genital mutilation in Egypt..J Inj Violence Res.2010: 2:41-5.

8. Matthews B. Female genital mutilation: Australian law, policy and practical challenges for doctors. Med J Aust.2011:194(3):139-41.

9. UNCIEF. Female Genital Mutilation/Cutting: A statistical overview and exploration of the dynamics of Change.UNICEF. ISBN 978-92-806-47037.2013: Available from: http://www.childinfo.org/files/FGCM_Lo_r es.pdf. (Accessed January 2018).

10. El-Zanaty F, Way A. Egypt Demographic and Health Survey 2000. Calverton, Maryland, Ministry of Health and Population (Egypt), National Population Council and ORC Macro.2001; Genital mutilation? Eastern Mediterranean Health Journal.2000:12 (Supplement 2).

11. WHO, UNFPA. Towards the Elimination of Female Genital Mutilation: A Training Manual for the Affected Countries in the Eastern Mediterranean Region. Cairo: World Health Organization Regional Office for the Eastern Mediterranean.2006: 115;5060

12. Gaali M, Strevens H, Mardh P. Female genital mutilation - an exported medical hazard.Eur J Contracept Reprod Health Care.2005:10(2):93-7.

13. Van der Osten, Sacken T, Uwer T. Is female genital mutilation an Islamic problem? 
2007; Available from:

http://www.meforum.org/1629/is-female-

genital-mutilation-anislamic-

problem.(Accessed November 2017).

14. Amin T, Abdelmoaty A, Sabry H . Female genital mutilation: Egypt in Focus. Eur J Forensic Sci.2017: 4(1):24-28.

15. Tag-Eldin MA, Gadallah MA, Al-Tayeb $\mathrm{MN}$, et al. Prevalence of female genital cutting among Egyptian girls.Bull World Health Organization.2008: 86(4):269-74.

16. El-Gibaly O, Ibrahim B, Mensch BS et al. The decline of female circumcision in Egypt: evidence and interpretation. Soc Sci Med.2002:54(2):205-20.

17. Rasheed SM, Abd-Ellah AH, Yousef FM. Female genital mutilation in Upper Egypt in the new millennium.International Journal of Gynecology and Obstetrics 2011:114;4750.

18. Abdulcadir J, Rodriguez MI, Say L. Research gaps in the care of women with female genital mutilation: an analysis.2015: BJOG;122(3):294-303.

19. Balfour J, Abdulcadir J, Say L, Hindin MJ . Interventions for healthcare providers to improve treatment and prevention of female genital mutilation: a systematic review.BMC Health Services Research.2016:16:409 DOI 10.1186/s12913-016-1674-1.
20. Herieka E, Dhar J . Female genital mutilation in the Sudan: survey of the attitude of Khartoum university students towards this practice. 2003; Sex Transm Infect; 79:220-223.

21. Relph S, Inamdar R, Singh $\mathrm{H}$ et al. Female genital mutilation/cutting: knowledge, attitude and training of health professionals in inner city London European. Journal of Obstetrics \& Gynecology and Reproductive Biology.2013: 168 (195-198).

22. Zaidi N. Knowledge of female genital mutilation among healthcare professionals.Journal of Obstetrics and Gynecology. 2007: 27:161-4.

23. El-Zanaty F . Factors and determinants of FGM/C of girls aged 0-17 years.2015; a secondary analysis of the Egypt Demographic and Health Surveys, 2005, 2008 and 2014. Unicef Egypt.2015: 30:4045.

24. Refaat AH, Dandash KF, Lotfy $G$ et al. Attitudes of Medical Students towards Female Genital Mutilation. Journal of Sex \& Marital Therapy. 2001: 27:589-591. 
Abdelmoaty et al: Knowledge, Attitude and Practice of Female Genital Mutilation

Table (1): Knowledge about Female Genital Mutilation/cutting (FGM/C) among the surveyed Medical Students at Cairo University distributed by gender

\begin{tabular}{|c|c|c|c|c|}
\hline \multirow[t]{2}{*}{ Knowledge items } & \multicolumn{2}{|l|}{ Gender: no. (\%) } & \multirow{2}{*}{$\begin{array}{l}\text { Total: no. } \\
(\%)\end{array}$} & \multirow[t]{2}{*}{$P$ value } \\
\hline & Males $(n=260)$ & Females $(n=370)$ & & \\
\hline $\begin{array}{l}\text { Known types of FGM: } \\
\text { - None } \\
\text { - One } \\
\text { - Two } \\
\text { - Three } \\
\text { - } \text { Four types }\end{array}$ & $\begin{array}{l}104(40.0) \\
75(28.8) \\
40(15.4) \\
29(11.2) \\
12(4.6)\end{array}$ & $\begin{array}{l}126(34.1) \\
117(31.6) \\
65(17.6) \\
50(13.5) \\
12(3.3)\end{array}$ & $\begin{array}{l}230(36.5) \\
192(30.5) \\
105(16.7) \\
79(12.5) \\
24(3.8)\end{array}$ & $0.440^{*}$ \\
\hline $\begin{array}{l}\text { All forms of FGM are harmful: } \\
\text { - Yes } \\
\text { - No } \\
\end{array}$ & $\begin{array}{l}141(54.2) \\
119(45.8) \\
\end{array}$ & $\begin{array}{l}229(61.9) \\
141(38.1)\end{array}$ & $\begin{array}{l}370(58.7) \\
260(41.3)\end{array}$ & $0.030 *$ \\
\hline $\begin{array}{l}\text { Identified possible reproductive } \\
\text { complications of FGM: } \\
\text { - None } \\
\text { - One- two } \\
\text { - Three-four } \\
\text { - More than four }\end{array}$ & $\begin{array}{l}10(3.8) \\
33(12.7) \\
111(42.7) \\
106(40.8)\end{array}$ & $\begin{array}{l}13(3.5) \\
52(14.0) \\
142(38.4) \\
163(44.1)\end{array}$ & $\begin{array}{l}23(3.7) \\
85(13.5) \\
253(40.2) \\
269(42.6)\end{array}$ & $0.580^{*}$ \\
\hline $\begin{array}{l}\text { FGM is an evidence-based good } \\
\text { practice: } \\
\text { - Yes } \\
\text { - No }\end{array}$ & $\begin{array}{l}54(20.8) \\
206(79.2)\end{array}$ & $\begin{array}{l}59(15.9) \\
311(84.1)\end{array}$ & $\begin{array}{l}113(17.9) \\
517(82.1)\end{array}$ & $0.070^{*}$ \\
\hline $\begin{array}{l}\text { FGM decreases promiscuity: } \\
\text { - Yes } \\
\text { - } \text { No } \\
\end{array}$ & $\begin{array}{l}195(75.0) \\
65(25.0)\end{array}$ & $\begin{array}{l}210(56.8) \\
160(43.2)\end{array}$ & $\begin{array}{l}405(64.3) \\
225(35.7)\end{array}$ & $0.001 *$ \\
\hline $\begin{array}{l}\text { FGM decreases sexual pleasure: } \\
\text { - } \quad \text { Yes } \\
\text { - } \quad \text { No }\end{array}$ & $\begin{array}{l}236(90.8) \\
24(9.2)\end{array}$ & $\begin{array}{l}346(93.5) \\
24(6.5)\end{array}$ & $\begin{array}{l}582(92.4) \\
48(7.6)\end{array}$ & $0.130 *$ \\
\hline $\begin{array}{l}\text { FGM causes sexual dysfunction: } \\
\text { Yes } \quad \text { - } \\
\text { No } \quad- \\
\end{array}$ & $\begin{array}{l}171(65.8) \\
89(34.2)\end{array}$ & $\begin{array}{l}232(62.7) \\
138(37.3)\end{array}$ & $\begin{array}{l}403(64.0) \\
227(36.0)\end{array}$ & $0.240^{*}$ \\
\hline $\begin{array}{l}\text { FGM makes genitalia more } \\
\text { attractive: } \\
\text { - Yes } \\
\text { - No }\end{array}$ & $\begin{array}{l}108(41.5) \\
152(58.5)\end{array}$ & $\begin{array}{l}140(37.8) \\
230(62.2)\end{array}$ & $\begin{array}{l}248(39.4) \\
382(60.6)\end{array}$ & $0.190 *$ \\
\hline $\begin{array}{l}\text { FGM increases the chance of } \\
\text { marriage: } \\
\text { - Yes } \\
\text { - No }\end{array}$ & $\begin{array}{l}16(51.6) \\
15(48.4)\end{array}$ & $\begin{array}{l}113(32.6) \\
234(67.4)\end{array}$ & $\begin{array}{l}129(34.1) \\
249(65.9)\end{array}$ & $0.020^{*}$ \\
\hline $\begin{array}{l}\text { FGM practice is against the laws: } \\
\text { - Yes } \\
\text { - No }\end{array}$ & $\begin{array}{l}177(68.1) \\
83(31.9)\end{array}$ & $\begin{array}{l}284(76.8) \\
86(23.2)\end{array}$ & $\begin{array}{l}461(73.2) \\
169(26.8)\end{array}$ & $0.010^{*}$ \\
\hline $\begin{array}{l}\text { Total knowledge score (10 points): } \\
\text { Mean } \pm \text { SD } \\
\text { Median (IQR) }\end{array}$ & $\begin{array}{l}4.5(1.7) \\
4.5(3.5-5.5)\end{array}$ & $\begin{array}{l}4.9(1.7) \\
5(4.0-6.0)\end{array}$ & $\begin{array}{l}4.7(1.7) \\
5(3.5-6.0)\end{array}$ & $0.001 * *$ \\
\hline
\end{tabular}

SD: standard deviation, IQR=interquartile range, *Chi-square, ${ }^{* *}$ Mann Whitney test.

$\mathrm{IQR}=$ interquartile range 
Table (2): Attitude towards Female Genital Mutilation/Cutting (FGM/C) among the surveyed Medical Students at Cairo University distributed by gender $(\mathbf{n}=630)$

\begin{tabular}{|c|c|c|c|c|}
\hline \multirow[t]{2}{*}{ Attitude items } & \multicolumn{2}{|c|}{ Gender: no. (\%) } & \multirow[b]{2}{*}{$\begin{array}{l}\text { Total: }(n=630) \\
\text { no. }(\%)\end{array}$} & \multirow[b]{2}{*}{ P value* } \\
\hline & $\begin{array}{l}\text { Males } \\
(n=260)\end{array}$ & $\begin{array}{l}\text { Females } \\
(n=370)\end{array}$ & & \\
\hline $\begin{array}{l}\text { Will encourage FGM: } \\
\text { - Agree } \\
\text { - } \text { Disagree } \\
\text { - Not decided }\end{array}$ & $\begin{array}{l}18(7.0) \\
209(81.6) \\
29(11.3)\end{array}$ & $\begin{array}{l}6(1.6) \\
327(89.3) \\
33(9.0) \\
\end{array}$ & $\begin{array}{l}24(3.9) \\
536(86.2) \\
62(10.0) \\
\end{array}$ & 0.001 \\
\hline $\begin{array}{l}\text { FGM should be legislated against: } \\
\text { - Yes } \\
\text { - No } \\
\text { - Don't know } \\
\end{array}$ & $\begin{array}{l}160(63.0) \\
31(12.2) \\
63(24.8) \\
\end{array}$ & $\begin{array}{l}281(77.4) \\
22(6.1) \\
60(16.5)\end{array}$ & $\begin{array}{l}441(71.5) \\
53(8.6) \\
123(19.9) \\
\end{array}$ & 0.001 \\
\hline $\begin{array}{l}\text { Males prefer circumcised females for } \\
\text { marriage: } \\
\text { - Agree } \\
\text { - Disagree } \\
\text { - Not decided } \\
\end{array}$ & $\begin{array}{l}10(4.3) \\
165(70.2) \\
60(25.5)\end{array}$ & $\begin{array}{l}5(20.8) \\
10(41.7) \\
9(37.5)\end{array}$ & $\begin{array}{l}15(5.8) \\
175(67.6) \\
69(26.6)\end{array}$ & 0.030 \\
\hline $\begin{array}{l}\text { FGM practice should continue: } \\
\text { - Yes } \\
\text { - No } \\
\text { - Don't know } \\
\end{array}$ & $\begin{array}{l}26(10.6) \\
186(75.6) \\
34(13.8) \\
\end{array}$ & $\begin{array}{l}13(3.6) \\
316(88.5) \\
28(7.9) \\
\end{array}$ & $\begin{array}{l}39(6.5) \\
502(83.3) \\
62(10.3) \\
\end{array}$ & 0.001 \\
\hline $\begin{array}{l}\text { Will have daughter circumcised: } \\
\text { - Yes } \\
\text { - No } \\
\text { - Not decided }\end{array}$ & $\begin{array}{l}12(5.1) \\
189(79.7) \\
36(15.2)\end{array}$ & $\begin{array}{l}12(3.5) \\
313(90.2) \\
22(6.3)\end{array}$ & $\begin{array}{l}24(4.1) \\
502(86) \\
58(9.9)\end{array}$ & 0.001 \\
\hline $\begin{array}{l}\text { In favour of FGM/C: } \\
\text { Given reasons for being in favour to FGM: } \\
\text { - Religious } \\
\text { - } \text { Cultural/social } \\
\text { - Sexual } \\
\text { - } \text { More than one reason }\end{array}$ & $\begin{array}{l}36(13.8) \\
26(10.0) \\
11(4.2) \\
13(5.0)\end{array}$ & $\begin{array}{l}42(11.4) \\
26(7.0) \\
9(2.4) \\
14(3.4)\end{array}$ & $\begin{array}{l}78(12.4) \\
52(8.3) \\
20(3.2) \\
27(4.3)\end{array}$ & 0.163 \\
\hline
\end{tabular}

*Chi-square for independent samples. 
Table (3): Predictors for Future Practicing of female genital mutilation/cutting (FGM/C) among the surveyed Medical Students at Cairo University

\begin{tabular}{|c|c|c|c|}
\hline \multirow[b]{2}{*}{ Socio-demographic characteristics } & \multicolumn{2}{|c|}{ Category: no. $(\%)$} & \multirow[b]{2}{*}{$\begin{array}{l}\text { Odds ratio } \\
(95 \% \\
\text { confidence } \\
\text { intervals) and } \\
\text { P value* }\end{array}$} \\
\hline & $\begin{array}{l}\text { In favour with } \\
\text { possible future } \\
\text { practicing of } \\
\text { FGM }(n=111)\end{array}$ & $\begin{array}{l}\text { Not in favour and } \\
\text { will not practice } \\
\text { FGM in the future } \\
(n=519)\end{array}$ & \\
\hline $\begin{aligned} \text { Sex } & \\
\text { - } & \text { Male } \\
\text { - } & \text { Female }\end{aligned}$ & $\begin{array}{l}56(50.5) \\
55(49.5)\end{array}$ & $\begin{array}{l}204(39.3) \\
315(60.7)\end{array}$ & $\begin{array}{l}1.57(1.04- \\
2.57) \\
0.020\end{array}$ \\
\hline $\begin{array}{l}\text { Age } \\
\text { - Less than or equal } 20 \text { years } \\
\text { More than } 20 \text { years }\end{array}$ & $\begin{array}{l}27(24.3) \\
84(75.7)\end{array}$ & $\begin{array}{l}166(32) \\
353(68)\end{array}$ & $\begin{array}{l}0.68(0.42- \\
1.09) \\
0.071\end{array}$ \\
\hline \begin{tabular}{ll}
\multicolumn{2}{l}{ Religion } \\
- & Muslims \\
- & Christians \\
\end{tabular} & $\begin{array}{l}103(92.8) \\
8(7.2)\end{array}$ & $\begin{array}{l}445(86.2) \\
71(13.8)\end{array}$ & $\begin{array}{l}2.05(0.96-4.4) \\
0.065\end{array}$ \\
\hline $\begin{array}{l}\text { Academic year } \\
\text { - Basic education: (2 } 2^{\text {nd }} \& 3^{\text {rd }} \\
\text { grades }) \\
\text { - Clinical education: }\left(4^{\text {th }} \text { to } 6^{\text {th }}\right. \\
\text { grades })\end{array}$ & $\begin{array}{l}59(53.2) \\
52(46.8)\end{array}$ & $\begin{array}{l}251(48.4) \\
268(51.6)\end{array}$ & $\begin{array}{l}1.2(0.8-1.8) \\
0.20\end{array}$ \\
\hline $\begin{array}{l}\text { Knowledge of FGM: } \\
\text { - } \quad \text { Knowledgeable }(\geq 6 \text { points }) \\
\text { - } \quad \text { Less knowledgeable (<6 points })\end{array}$ & $\begin{array}{l}102(91.9) \\
9(8.1)\end{array}$ & $\begin{array}{l}358(69) \\
161(31)\end{array}$ & $\begin{array}{l}5.09(2.51- \\
10.33) \\
0.001\end{array}$ \\
\hline
\end{tabular}

*Chi-square for independent samples 


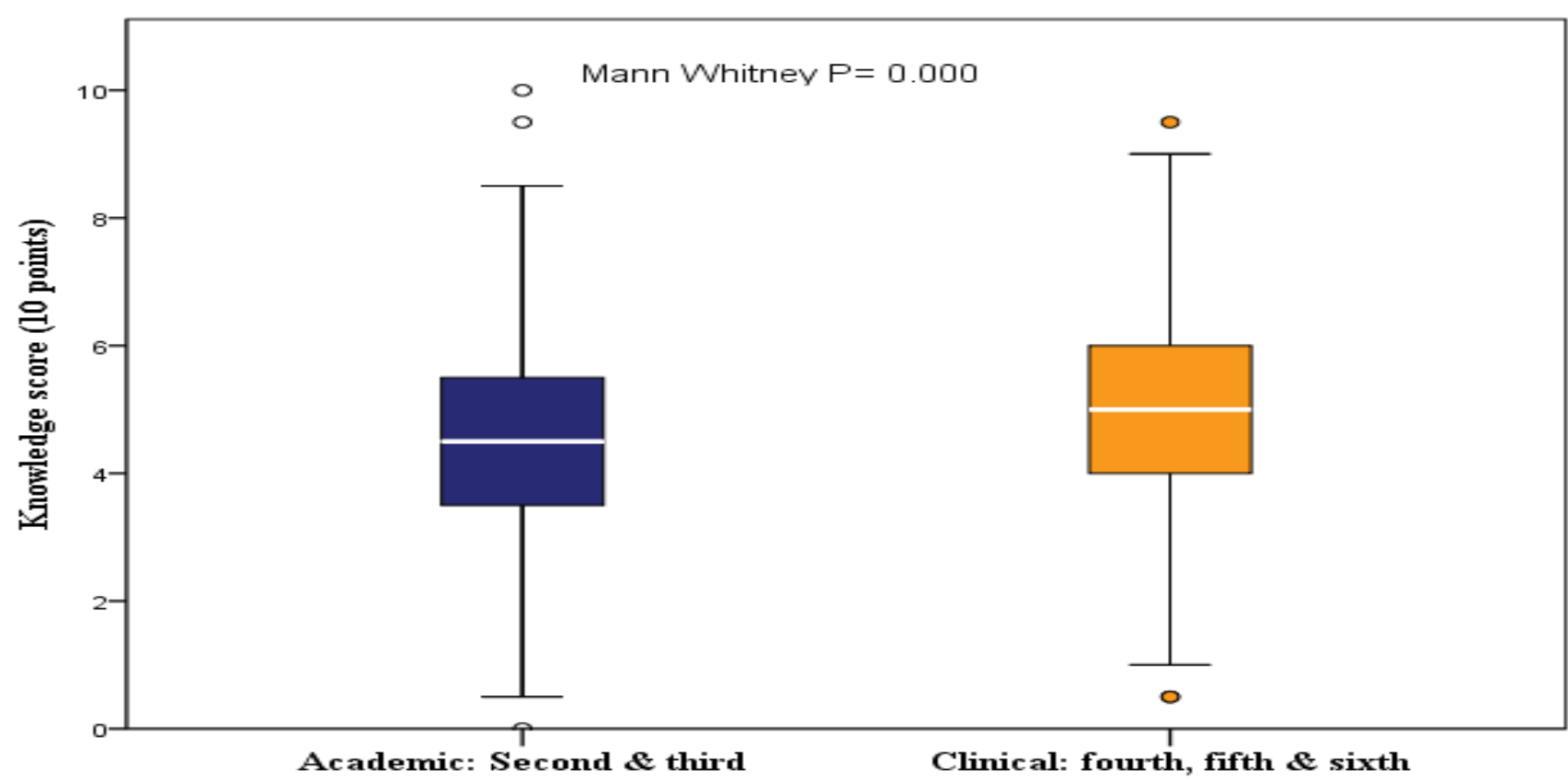

Figure (1): Knowledge score about female genital mutilation/cutting (FGM/C) for different types of medical education (academic vs. clinical) of the surveyed students

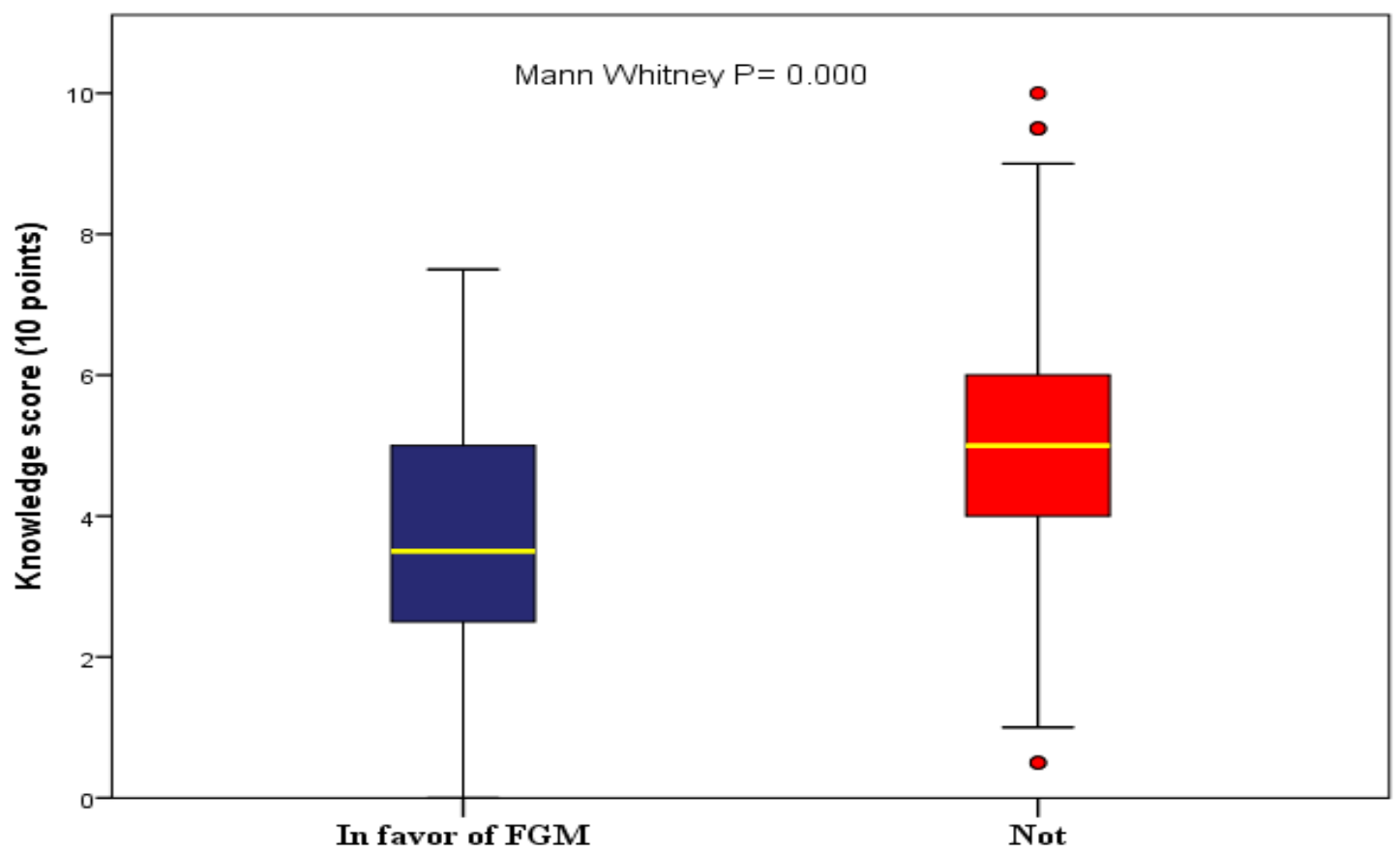

Figure (2): The total knowledge score in relation to being in favour of female genital mutilation/cutting FGM/C among the surveyed medical students 


\section{الملخص العربي \\ معرفة موقف ونية ممارسة ختان الاناث في المستقبل بين طلاب الطب_مصر المر \\ الثيماء محمد عبد المعطى- هند على صبرى- ريهام يسرى الامير}

الخلفية: لا يوجد أي مؤشر طبي لتشويه / بتر الأعضاء التناسلية للإناث (ختان الإناث) وهو إجراء ذو مجموعة و اسعة من المضاعفات. حو الي 50 ٪ من السكان يدعمون هذه الممارسة في مصر؛ علاوة على ذلك، يتم إجر اء حو الي 80 ٪ من تثويه الأعضاء التناسلية الأنثوية من قبل مقدمي الرعاية الصحية خلافا لدور هم الأصلي في القضاء على هذه الممارسة الضارة. معرفة وموقف طلاب الطب فى مصر حول نشويه الأعضاء التناسلية الأنثوية محل تسائل ـالأهداف: استكثاف مدى معرفة وموقف طلاب الطب تجاه ختان الإناث ومعر فة المحددات التي تتنبأ بالممارسة المحتملة لهؤ لاء الذين يفضلون ممارستها الطريقة: در اسة مستعرضة، تم تضمين 630 من طلاب الطب. تم استخدام نموذج لجمع البيانات يتم ملؤه ذاتيا دون ذكر الهوية. النتائج: أظهرت الإناث درجة كبيرة من المعرفة 4.5-5.5 4.5ع موقف أكثر سلبية تجاه ختان الإناث. وكان الذكور الذين يعانون من درجة معرفة منخفضة (6-4) 5 هم المتنبىء الاكبر لممارسة ختان الإناث في المستقبل بين العينة المدرجة .الاستتتاجات: طلاب الطب، وخاصة الذكور ، ليسو ا على در اية كافية بالختان، وبعضهم سيؤدي ختان الإناث في المستقبل. 